\title{
MAKSIMALISASI PENGGUNAAN LABORATORIUM KOMPUTER SEKOLAH BERSPESIFIKASI STANDAR DALAM PEMBUATAN ANIMASI PIXEL DALAM EXCEL
}

\author{
Nurussama $^{*}$, Dilmai Putra ${ }^{2}$ \\ ${ }^{1}$ Jurusan Akuntansi, Program Studi Akuntansi, Politeknik PalComTech, Palembang, Indonesia \\ ${ }^{2}$ Jurusan Desain Komunikasi Visual, Program Studi Desain Komunikasi Visual, Politeknik PalComTech, \\ Palembang, Indonesia \\ *Penulis Korespondensi: nurussama@palcomtech.ac.id
}

\begin{abstract}
Abstrak
Kegiatan pengabdian bagi masyarakat ini bertujuan untuk memberikan pengetahuan dan keterampilan pada guru-guru dalam pemanfaatan informasi teknologi (IT) yang terintegrasi program microsoft excel yang inovatif dalam upaya meningkatkan mutu pendidikan. Tujuan lainnya adalah berbagi ilmu pengetahuan dan pemahaman bagaimana merancang dan menggunakan aplikasi microsoft excel dalam membuat animasi pixel dalam excel untuk guru sehingga turut berupaya memaksimalkan keterampilan kualitas sumber daya manusia (SDM) guru di SMK Bina Jaya Palembang. Metode yang dipakai dalam menghadapi persoalan mitra adalah observasi dan survei langsung ke obyek penelitian sehingga dapat berdialog dan berdiskusi langsung dengan mitra dalam kesepakatan mencari solusi persoalan yang menjadi prioritas, seleksi konsep yang akan digunakan, penyusunan kegiatan pelatihan, rencana kegiatan, mitra turut terlibat sebagai peserta pelatihan hingga implementasi langsung sebagai pengguna program microsoft excel dan evaluasi hasil bersama-sama. Kegiatan pengabdian bagi masyarakat ini akan menghasilkan peningkatan jasa dan metode yang masing-masing meliputi aspek kehidupan bermasyarakat, aspek mutu layanan dan aspek sosial dengan sasarannya adalah guru SMK Bina Jaya, di Kemas Rindo kertapati, Kota Palembang.
\end{abstract}

Kata kunci: Ipteks, Animasi Pixel, Microsoft Excel, Aspek Mutu Layanan.

\begin{abstract}
The activity of dedication to society aimed to provide knowledge and skills to teachers in the use of information technology (IT) which was integrated with innovative Microsoft Excel programs in an effort to improve the quality of education. Another goal was to share knowledge and understanding on how to design and use Microsoft Excel applications in creating pixel animations in Excel for teachers so that they also tried to maximize the skills of quality human resource (HR) teachers at Bina Jaya Vocational High School Palembang. The methods which were used in dealing with partner issues were observation and surveys directly to the object of research so that they could have a dialogue and discussed directly with the partners in an agreement to find solutions of problems that are prioritized, concept selection would be used, preparation of training activities, activity plans, and partners were involved as participants of training, did direct implementation as Microsoft Excel program users and did evaluation of results together. Community service activities would improve services and methods, each of which includes aspects of community life, aspects of service quality and social aspects of which objects were teachers of Bina Jaya Vocational High School Palembang, at Kemas Rindo Kertapati, Palembang.
\end{abstract}

Keywords: Science and Technology, Pixel Animation, Microsoft Excel, Service Quality Aspects.

\section{PENDAHULUAN}

Perkembangan manusia dalam berbagai aspek kehidupan bermasyarakat turut berpengaruh pada sektor pendidikan sehingga pendidikan pun ikut mengalami dinamika yang semakin berkembang. Itulah sebabnya pendidikan yang dirasakan anak-anak pada masa 10 tahun yang lalu berbeda secara signifikan dengan pendidikan yang dialami anak-anak pada jaman sekarang ini. Hal ini tentu sangat erat kaitannya dengan beragam inovasi yang muncul dalam perkembangan manusia, salah satunya adalah teknologi informasi (IT). Teknologi informasi sudah menjadi kebutuhan umum bagi semua kalangan, tak terkecuali pada bidang pendidikan. Pada hakikatnya proses belajar mengajar adalah proses komunikasi yang harus diciptakan atau diwujudkan melalui kegiatan penyampaian dan tukar 
menukar pesan atau informasi oleh setiap tenaga pengajar dan peserta didik (Awaliah, 2013). Siswa perlu dibekali dengan kemampuan untuk belajar sepanjang hayat, belajar dari aneka sumber, belajar bekerja sama, beradaptasi, dan menyelesaikan masalah (Sani, 2014). Para ahli pembelajaran sependapat bahwa kemampuan pemecahan masalah dalam batas-batas tertentu, dapat dibentuk melalui bidang studi dan disiplin ilmu yang diajarkan (Wena, 2012).

Akan tetapi, perkembangan beragam inovasi teknologi informasi tidak searah dengan pola pemanfaatan yang tepat guna bagi sentra pendidikan yang dalam artian pemanfaatan penggunaan teknologi informasi belum merata dikuasai dan di kelola oleh perangkat elemen pendidikan. Perangkat elemen pendidikan yang dimaksud adalah guru maupun siswa, hal ini disebabkan oleh kurangnya pengetahuan dan sosialisasi pemanfaatan teknologi informasi yang tepat guna sehingga dapat di kelola untuk mendukung dan meningkatkan mutu pendidikan itu sendiri. Hal ini nampak pada SMK Bina Jaya yang berada di Kemas Rindo Kertapati. Kemas Rindo Kertapati merupakan salah satu kecamatan yang padat penduduk di Kota Palembang sehingga tidak heran apabila kecamatan ini masih berjalan pada tahap pengembangan yang belum sempurna pada segala aspek. Kepadatan penduduk di Kecamatan Kertapati berjumlah 19,93 jiwa per $\mathrm{Ha}$ (hektar), dimana Kelurahan Ogan Baru memiliki kepadatan penduduk terbesar dibandingkan dengan kelurahan-kelurahan lain yang ada di Kecamatan Kertapati yaitu 227,35 jiwa per hektar (Palembang, 2018).

SMK Bina Jaya sendiri memiliki visi sebagai lembaga pendidikan dan pelatihan kejuruan yang mampu menghasilkan tenaga kerja terampil tingkat menengah yang siap bekerja dalam dunia usaha dan dunia industri, melakukan usaha mandiri, dan melanjutkan pendidikan di jenjang pendidikan tinggi. Perkembangan teknologi yang menjadi salah satu titik kemajuan dalam dunia pendidikan di SMK Bina Jaya. Dalam memenuhi tuntutan teknologi, SMK Bina Jaya memiliki fasilitas laboratorium komputer dalam implementasi pembelajarannya, namun dengan keterbatasan teknologi dan pengetahuan yang ada. Siswa-siswi lebih tertarik menggunakan sosial media sebagai tempat berekspresi membuat foto, video dan mengunggahnya ke sosial media, hal ini membuat tim pengabdi tertarik untuk mengajarkan bagaimana dengan kondisi keterbatasan laboratorium yang ada, dapat menarik minat siswa siswi agar lebih mengeksplorasi kemampuan mengolah atau membuat animasi menggunakan sarana sekolah, salah satunya membuat animasi menggunakan microsoft excel. Terbatasnya spesifikasi peralatan di laboratorium SMK Bina Jaya akan kami solusikan dengan pemanfaatan yang optimal, bahwa membuat animasi tak hanya harus menggunakan software dengan dengan spesifikasi tinggi, namun juga dapat menggunakan microsoft salah satunya program microsoft excel yang dimiliki oleh komputer di SMK Bina Jaya. Berbagai sosialisasi dan upaya pelatihan guru telah dilakukan oleh fasilitator kurikulum yang bergerak di bidang pengembangan serta perangkat sekolah namun hasilnya masih dibutuhkan banyak pelatihan yang berkelanjutan demi memenuhi salah satu misi SMK Bina Jaya yaitu mengoptimalkan kemampuan akademik dalam rangka menyiapkan siswa sebagai tenaga kerja yang adaptif dalam perkembangan ilmu pengetahuan dan teknologi, kebutuhan dunia usaha dan dunia industri 4.0.

Bahan: Adapun materi yang tim pengabdi sampaikan dalam kegiatan ini adalah sebagai berikut:

\section{A. Aspek Mutu Layanan}

Proses pendidikan dan pembelajaran dalam kelas, bukan hanya untuk memperdalam pengetahuan, tetapi juga untuk mempertinggi sikap kritis dan daya kreatif dalam menghadapi peserta didik. Terkait uraian pada aspek kehidupan bermasyarakat di atas maka hal tersebut erat kaitannya dengan aspek mutu layanan. Guru sebagai "main person" harus meningkatkan kompetensinya untuk mendukung suatu pendidikan yang bermutu dan berkualitas melalui pelayanan pengajarannya yang berinovasi. Peran guru harus berubah dari : sebagai penyampai pengetahuan, sumber utama informasi, sumber segala jawaban menjadi seorang fasilitator pembelajaran, pelatih dan mitra belajar bagi siswa. Selanjutnya guru dari mengendalikan dan mengarahkan semua aspek pembelajaran, menjadi lebih banyak memberikan beragam alternatif dalam proses pembelajaran. Hal-hal tersebut belum sepenuhnya diterapkan pada SMK Bina Jaya dalam proses pengajaran, tentu sangat membutuhkan optimalisasi kemampuan pemanfaatan teknologi informasi (IT) sebagai pra syarat untuk meningkatkan mutu pendidikan. Berdasarkan hal-hal tersebut diatas maka timbul suatu pemikiran untuk mencari strategi baru dalam kegiatan penyelenggaraan kegiatan pembelajaran untuk lebih memberikan motivasi dan menarik minat belajar siswa SMK Bina Jaya dengan menerapkan suatu pola pembelajaran dan teknik penyampaian materi yang dikemas dalam "scrollbook". Scrollbook dapat diartikan sebagai versi digital flipbook dengan scrolling yang menggantikan flipping terhadap halamannya. Halaman excel akan menjadi frame animasinya, dan cell akan menjadi pixelnya. Pelatihan ini akan menunjukkan pengembangan pembelajaran microsoft excel berguna untuk membuat animasi pixel yang enak dipandang dengan hanya menggunakan spreadsheet.

Dari uraian aspek kehidupan bermasyarakat dan aspek mutu layanan diatas, tentunya dikendalikan oleh aspek sosial. Pada dasarnya, lingkungan sekolah merupakan tempat berinteraksi antara guru dan siswa pada proses belajar-mengajar. Dengan upaya pemanfaatan informasi teknologi melalui pengembangan pengetahuan ini maka diharapkan ketika guru mengajar dan memfasilitasi interaksi sosial kepada para siswa dengan memasukkan berbagai pelajaran dalam bentuk hiburan yang dapat menarik minat dan motivasi siswa seperti misalnya potongan acara televisi, selingan games komputer saat jam pelajaran berlangsung. Interaksi sosial seperti ini tentu membantu proses pendidikan dan pengajaran sehingga para siswa dapat dengan mudah menangkap 
esensi dari pembelajaran itu sendiri tanpa merasa beban bahwa mereka tengah belajar. Interaksi sosial yang terjadi selama ini pada SMK Bina Jaya memang masih monoton dan terpusat pada guru. Guru merupakan sentra pengetahuan sehingga berakibat kurangnya daya kreatif dan partisipasi yg aktif dari siswa dalam menerima pembelajaran. Hal ini tentunya menghambat peningkatan mutu pendidikan itu sendiri karena siswa yang pasif dalam proses pembelajaran berlangsung. Pembelajaran merupakan salah satu sub sistem yang tidak luput dari arus perubahan yang disebabkan oleh kehadiran informasi teknologi sehingga pemanfaatan yang optimal dan sesuai sasaran nantinya dapat membantu meningkatkan kualitas pembelajaran di kelas sebagai alat bantu interaksi pembelajaran dan sekaligus merubah paradigma aspek sosial dalam kelas yakni pembelajaran yang berfokus pada siswa.

\section{Tutorial Praktik Spreadsheet}

Spreadsheet merupakan aplikasi komputer yang mensimulasikan kertas. Aplikasi ini menampilkan beberapa sel, biasanya dalam bentuk matriks atau dua dimensi terdiri atas baris dan kolom. Setiap selnya berisi teks alfanumerik, nilai numerik, atau rumus atau formula. Kanvas Spreadsheet. Mulai dengan membuat dokumen baru dan pilih page layout entah di tab layout atau pada tombol kiri bawah:

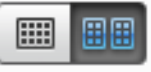

Gambar 1. Menu Page Layout (Sumber pengabdi, 2019).

Pada menu dropdown zoom level pilih One Page:

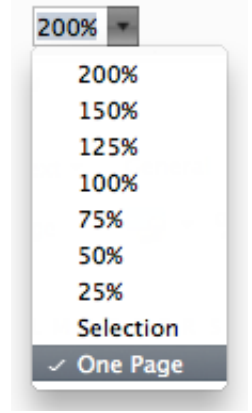

Gambar 2. Menu Dropdown Zoom (Sumber pengabdi, 2019).

Sekarang halaman tersebut akan selalu berada pada posisi yang sama kapanpun melakukan scroll. Halaman tersebut sekarang berfungsi sebagai frame animasi. Untuk membuat ukuran cell menjadi persegi pilih select all (Command-A) lalu masuk ke menu Cells > Format pada tab home. Di situ, ganti row height menjadi $0.55 \mathrm{~cm}$ dan column width menjadi $0.55 \mathrm{~cm}$.

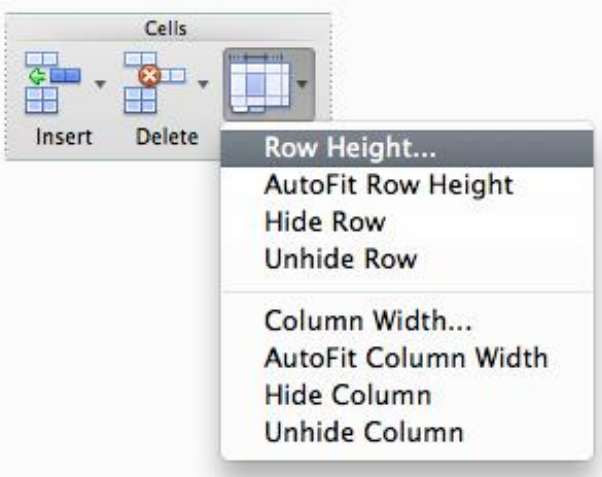

Gambar 3. Menu Membuat Ukuran Cell (Sumber pengabdi, 2019).

Dapat pula menggunakan pixel yang lebih kecil atau lebih besar, namun pixel ini jika pada ukuran page letter US akan memberikan resolusi $31 \times 40$ px yang sangat cocok untuk sebuah animasi simpel yang akan dibuat "31x40" sedikit mengganggu, dan karakter akan lebih terpusat jika jumlah pixel horisontal genap, namun mencoba menyamakan seluruh column widths hanya akan menghasilkan angka yang ganjil untuk beberapa alasan tertentu, jadi untuk menurunkan resolusi ke 30x40, maka harus mengubah lebar kolom A, B dan AC, AD ke $0.65 \mathrm{~cm}$.

\section{Semuanya Cell, tidak ada angka}

Kanvas sudah siap, pembuatan animasi orang yang melompat, dan gerakannya akan dibuat berulang-ulang sehingga kita dapat dengan mudah memperpanjang durasi animasi. Karakter yang dibuat ini sangat sederhana akan memiliki kepala berukuran 2x3 px. Dapat pula mengganti desain kepalanya namun, mungkin perlu menggunakan aplikasi penggambar seperti photoshop untuk melakukan itu, jadi dapat lebih bebas mencoba alternatif sebelum memutuskan untuk menggambar ulang desain pada cell spreadsheet. Sebaiknya meletakkan kepala pada kolom O dan $\mathrm{P}$ dan baris 21-23. Pilih cell tersebut:

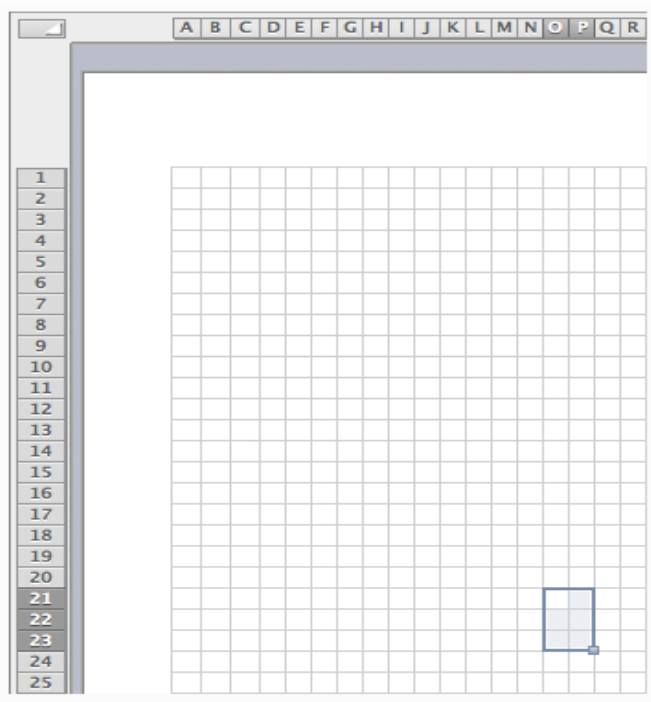

Gambar 4. Memilih cell untuk bagian pertama karakter: kepalanya (Sumber pengabdi, 2019). 
Klik kanan pada cell yang dipilih dan masuk ke Format Cells... (atau tekan Command-1) dan masuk ke tab fill dan pilih warna yang gelap, anda dapat menggunakan custom color namun karena anda akan melakukan ini berulang kali akan lebih baik untuk menggunakan theme colors. Badan karakter akan berukuran 4x6 px, kakinya 6 px vertikal dan lengannya 4px melintang.

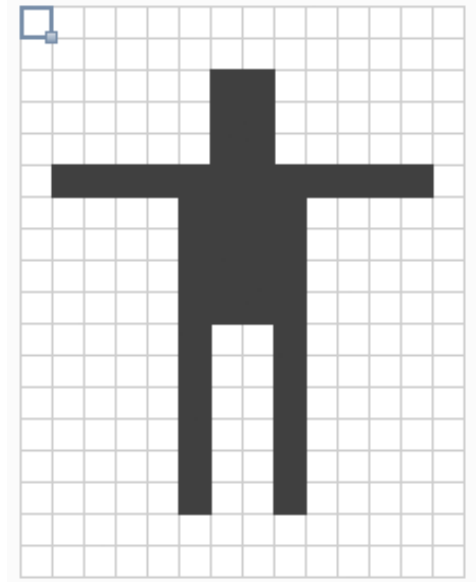

Gambar 5. Menaikkan Cell Terpilih dan Blok Cell dengan Menahan Tombol Command (Sumber pengabdi, 2019).

Dalam penambahan bayangan menggunakan pattern option. Juga dapat menggunakan abu-abu cerah untuk bayangannya namun dalam praktiknya agar sama mari menggunakan nuansa retro karena pattern. Patterns berada dalam tab yang sama dengan Format Cells > Fill namun letaknya berada di option Foreground.

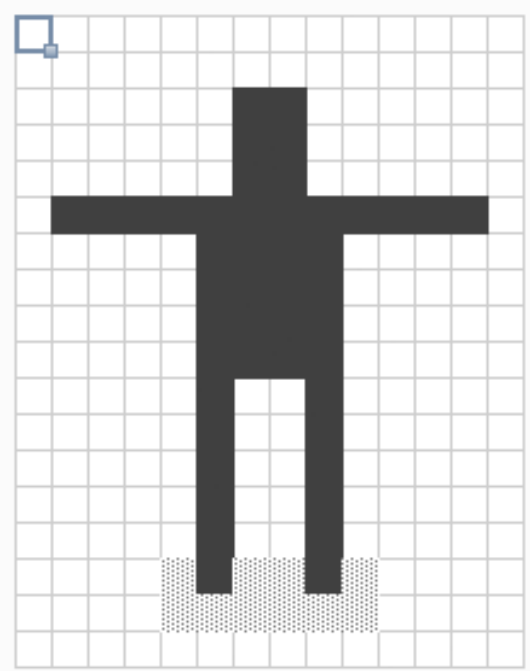

Gambar 6. Frame 1 (dari 11) Sudah Lengkap (Sumber pengabdi, 2019).

Pilih seluruh cell dari halaman tersebut dan copy, kemudian scroll ke halaman kedua, pilih cell A1 dan paste. Perubahan pada frame 2 adalah si karakter melenturkan tangannya untuk melompat hanya dengan memperpendeknya sebanyak 1 px, dan juga menurunkan lengannya sebanyak 1 px pada bahu dan 1 px lainnya di tengah, seperti ini:

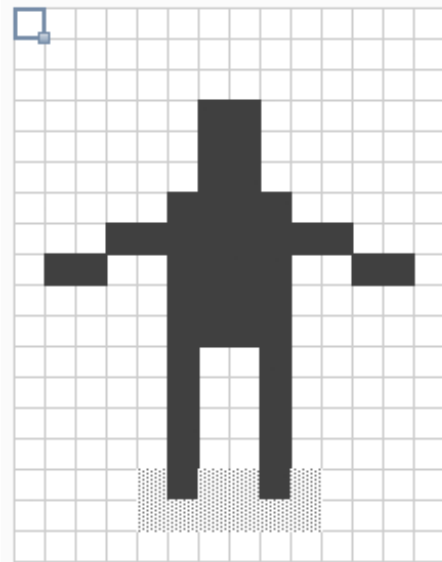

Gambar 7. Frame Melenturkan Tangan (Sumber pengabdi, 2019)

\section{Mengubah Excel Menjadi Viewer Animasi}

Untuk membungkus file tersebut, perlu ke layout > view, dan uncheck headings, untuk menghindari jumlah cell bergerak sedikit ketika menjadi 4 digit. Anda dapat juga uncheck gridlines untuk menghilangkan border cell, itu akan tampak lebih bersih namun akan kurang tampak seperti spreadsheet, jadi semuanya tergantung anda apakah menampilkannya atau tidak.

\section{B. Tempat Pengabdian}

Waktu pelaksanaan pengabdian ini adalah 1 hari dan terhitung dari persetujuan kontrak. Pengabdian ini akan dilakukan pada lokasi mitra pada SMK Bina Jaya Kertapati-Palembang. Observasi lapangan dilakukan dengan melakukan survey langsung maupun diskusi dengan mitra yakni wakil kurikulum Bapak Sobirin, S.Pd. dan kelompok guru pada SMK Bina Jaya untuk mengetahui permasalahan yang dihadapi oleh mitra, dan yang menjadi kebutuhan prioritas mitra adalah : 

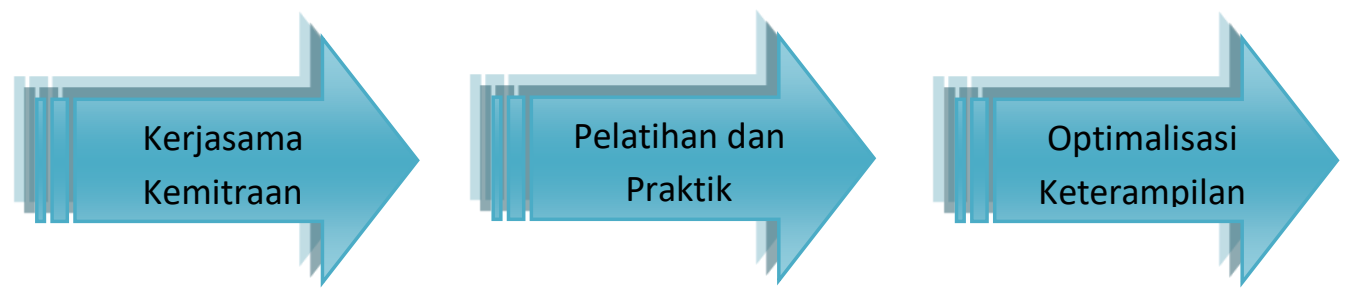

Gambar 8. Kebutuhan Prioritas Mitra (Sumber pengabdi, 2019).

1. Kerjasama Kemitraan

Sangat dibutuhkan kerjasama kemitraan antara mitra dan Perguruan Tinggi (PT) untuk mendukung profesi mitra dalam mengembangkan life skill metode pengajarannya menjadi lebih baik.

2. Pelatihan dan praktik

Perlu diadakan pelatihan bagi mitra untuk dapat meningkatkan mutu pendidikan dasar terpadu melalui pemahaman dan praktik metode pemanfaatan informasi teknologi (IT) melalui program yang terintegrasi.

3. Optimalisasi Keterampilan dan Kualitas Sumber Daya Manusia Dalam Meningkatkan Mutu Pendidikan Dasar Terpadu

Sangat diperlukan suatu metode untuk menerapkan ketrampilan pengajar berupa optimalisasi pemanfaatan informasi teknologi (IT) dan perangkat multimedia yang menunjang edutainment sebagai media ajar yang inovatif.

\section{METODE}

Prosedur kerja dalam penyelesaian permasalahan yang di hadapi mitra adalah sebagai berikut:

1. Identifikasi mengenai permasalahan yang ada untuk mencari solusi dengan proses "Brainstorming" terhadap persoalan tersebut untuk mengetahui apa yang menjadi kebutuhan mitra.

2. Merancang model karya program microsoft excel yang akan dilaksanakan dengan menyusun apa saja yang menjadi kebutuhan mitra dalam proses pembelajaran dalam kelas berdasarkan informasi, menentukan konsep yang tepat, menentukan spesifikasi alat dan bahan yang digunakan.

3. Pelaksanaan pelatihan guru-guru SMK Bina Jaya, dalam memanfaatkan aplikasi program microsoft excel serta diskusi tentang kendalakendala yang dihadapi dalam pemanfaatan aplikasi program microsoft excel di sekolah.

4. Pemantauan terhadap proses pelatihan sebagai wujud pendampingan penggunaan aplikasi program microsoft excel oleh guru sebagai user/pengguna aplikasi.

5. Setelah mitra dibekali dengan pengetahuan dan pelatihan, mitra siap menerapkannya pada proses pembelajaran bidang studi yang lainnya.
Beberapa metode yang digunakan dalam pengabdian adalah sebagai berikut:

1. Metode Ceramah

untuk penyampaian informasi pengetahuan dasar tentang teknologi informasi (IT), dasar internet, dasar multimedia dan optimalisasi pemanfaatannya serta prinsip kerjanya.

2. Metode diskusi/tanya jawab untuk mendiskusikan hal-hal yang belum dipahami oleh peserta sehubungan dengan pelatihan pemanfaatan aplikasi program microsoft excel.

3. Metode Pelatihan

digunakan untuk penyampaian materi pelatihan dan praktik langsung menyusun bahan ajar bidang studi yang menjadi contoh praktik serta bersama-sama menyisipkan multimedia pada aplikasi yang dikerjakan hingga pelaksanaan simulasi penggunaan aplikasi program microsoft excel.

4. Metode Demonstrasi

digunakan untuk mendemonstrasikan bagaimana menggunakan dan mengolah data pada aplikasi program microsoft excel.

\section{HASIL DAN PEMBAHASAN}

\section{Kerjasama Kemitraan}

Sangat dibutuhkan kerjasama kemitraan antara mitra dan Perguruan Tinggi (PT) untuk mendukung profesi mitra dalam mengembangkan life skill metode pengajarannya menjadi lebih baik. Terlaksananya pelatihan dan praktik animasi pixel dalam excel, kegiatan ini terselenggara dengan di ikuti oleh 15 guru SMK Bina Jaya. Pada pertemuan tersebut disampaikan informasi-informasi mengenai latar belakang, target, sasaran dan tujuan kegiatan pengabdian. Disamping menyampaikan maksud dan tujuan, juga dilakukan pencatatan data teknis lebih lanjut serta pencatatan visualisasi dalam foto. 


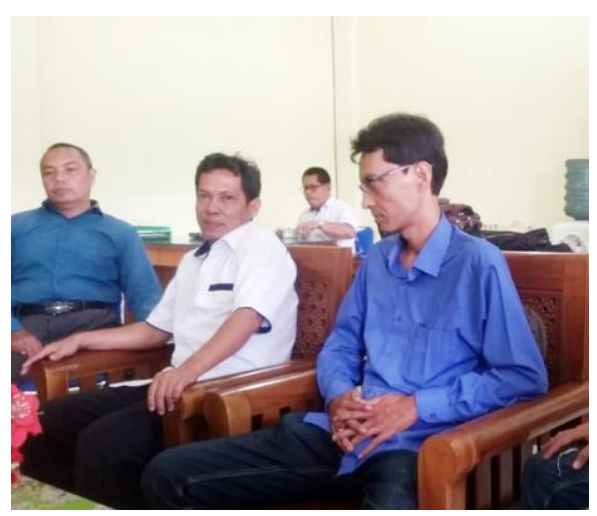

Gambar 9. Suasana diskusi bersama sebelum pelatihan di mulai (Sumber pengabdi, 2019).

\section{Pelatihan dan Praktik}

Pelatihan dan praktik animasi pixel dalam excel, ini dimulai dengan membagikan soal pre test yang berisi pertanyaan mengenai dasar-dasar microsoft excel sehingga membantu kami dalam mengetahui sejauh mana tingkat pengetahuan mitra dalam memahami materi. Setelah kami mengetahui kedalaman pengetahuan mitra maka kami mulai memberikan materi yang kami sesuaikan dengan tingkat pemahaman guru agar ketika memasuki sesi selanjutnya para guru telah memiliki dasar pengetahuan yang sama, sehingga pelatihan akan berjalan lebih efektif dan efisien.

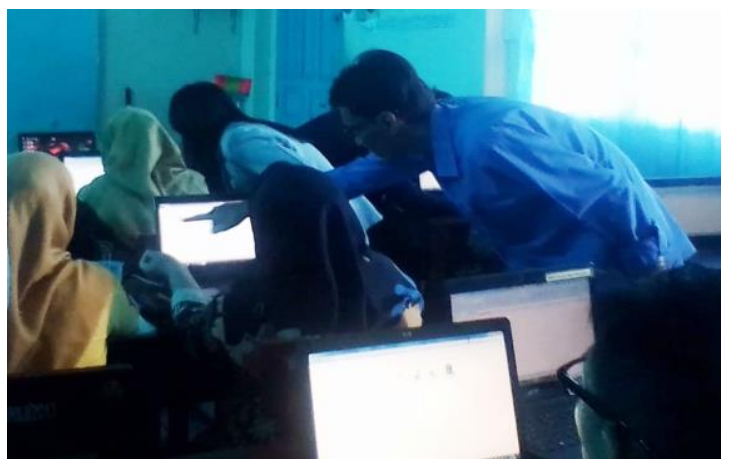

Gambar 10. Bapak Dilmai Putra, S.Sn., M.Sn. mengajari guru SMK Bina Jaya (Sumber pengabdi, 2019).

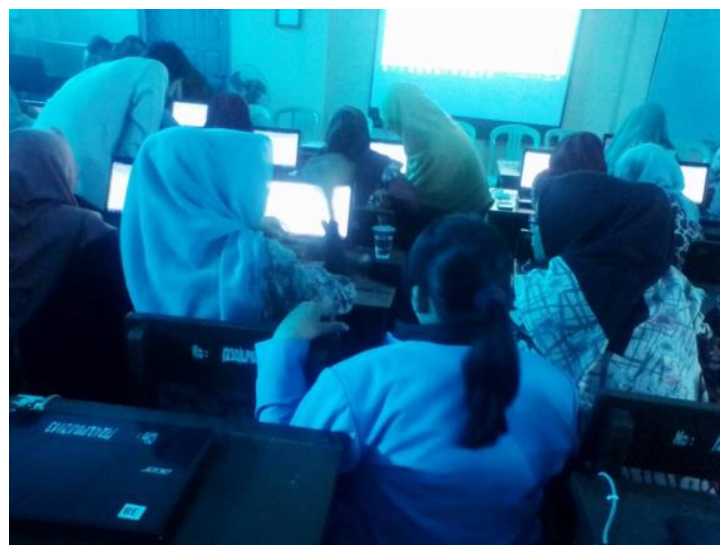

Gambar 11. Suasana Pemberian Pelatihan Praktik Pembuatan Animasi Excel (Sumber pengabdi, 2019).
Kegiatan ini diberikan oleh Nurussama, S.E., M.M. sebagai pakai manajemen yang membantu memberikan materi mengenai pengenalan microsoft excel dan Dilmai Putra, S.Sn., M.Sn. sebagai pakar animasi yang membantu mengarahkan guru dalam membuat animasi. Setelah kami memberikan materi dasar-dasar microsoft excel, maka kami memasuki pemberian materi praktik animasi pixel dalam excel.

\section{Optimalisasi Keterampilan dan Kualitas Sumber Daya Manusia Dalam Meningkatkan Mutu Pendidikan Dasar Terpadu}

Pada tahap ini merupakan kegiatan akhir pengabdian kami, dimana kami memberikan evaluasi kegiatan pelatihan dilakukan setelah pelatihan dan praktik animasi pixel dalam excel. Evaluasi kegiatan dilakukan untuk mengetahui keberhasilan kegiatan pelatihan yang dilaksanakan. Evaluasi dilakukan dengan cara memberikan post test yang berisi tentang pemahaman mitra selama berjalannya proses pengabdian berlangsung, dengan hasil kuesioner sebagai berikut:

Dalam penilaian tersebut kami membagi hasil post test dalam 3 (tiga) indikator penilaian seperti variabel pemahaman dasar microsoft excel, variabel pemahaman materi animasi pixel dalam excel kemudian variabel evaluasi mitra terhadap pelaksanaan pengabdian. Kesimpulan dari post test yang kami berikan adalah sebagai berikut:

1. Adanya peningkatan pemahaman pengetahuan mengenai dasar microsoft excel sebesar $75 \%$ dari hasil pre test sebelumnya.

2. Adanya penambahan pengetahuan dalam membuat animasi pixel dalam excel dengan indikator kesalahan dalam menjawab sebesar $36 \%$.

3. Untuk evaluasi terhadap kami sendiri rata-rata mitra menjawab sangat memuaskan sebesar $90 \%$.

4.

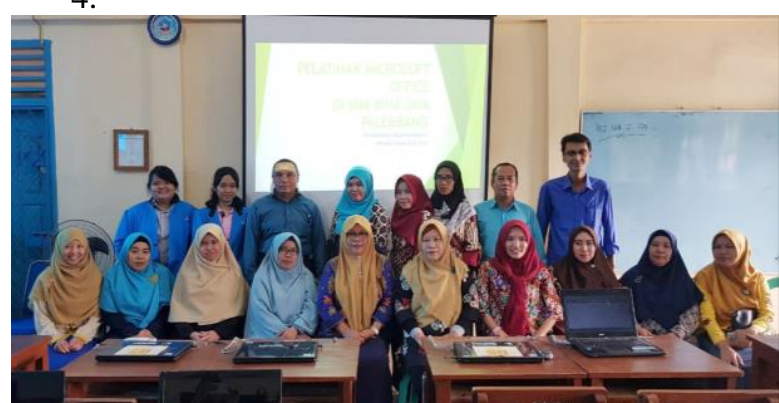

Gambar 12. Foto Dosen, Mahasiswa Politeknik PalComTech beserta Guru SMK Bina Jaya (Sumber pengabdi, 2019)

Selanjutnya kami juga meminta saran dan komentar yang membangun agar bertujuan menjadi evaluasi bagi pengabdian tim pelaksana dan menjadi masukan bagi pengabdian kampus selanjutnya.

\section{KESIMPULAN}

Berdasarkan hasil dari pelaksanaan kegiatan pengabdian kepada masyarakat untuk memaksimalkan 
penggunaan laboratorium computer sekolah yang berspesifikasi standar dalam pembuatan animasi pixel dalam excel, dapat disimpulkan melalui sosialisasi pelaksanaan kegiatan pengabdian masyarakat kepada kelompok mitra mampu meningkatkan pemahaman kelompok mitra terhadap kegiatan pengabdian masyarakat sebelum dan setelah kegiatan sebesar 51,8 $\%$ dan menambahkan pengetahuan anggota kelompok dalam memaksimalkan penggunaan laboratorium komputer sekolah yang memiliki spesifikasi standar agar dapat menciptakan animasi sederhana menggunakan excel. Selanjutnya melalui kegiatan pengabdian kepada masyarakat mampu memberikan nilai positif terhadap mitra, dengan adanya permintaan mitra untuk melakukan pengabdian kembali dengan tema teknologi yang inginkan mitra. Diharapkan setelah dilakukannya pengabdian kepada masyarakat ini, mampu meningkatkan pengetahuan mitra dalam mengajarkan siswa sebuah animasi sederhana yang dapat menarik minat siswa untuk menggunakan teknologi dalam berkarya digital.

\section{UCAPAN TERIMA KASIH}

Ucapan terima kasih disampaikan kepada Allah SWT, atas berkat rahmat-Nya pengabdi dapat menyelesaikan pengabdian ini dengan baik. Terimakasih juga diucapkan kepada kepala sekolah SMK Bina Jaya, wakil kurikulum beserta jajaran guru dan staf administrasi yang memfasilitasi tim pengabdian kepada masyarakat dan sekaligus menjadi objek pengabdian. Selanjutnya ucapan terima kasih juga disampaikan kepada seluruh tim pengabdian kepada masyarakat yang sudah berkontribusi pikiran dan waktu untuk mensukseskan kegiatan ini.

\section{DAFTAR PUSTAKA}

Awaliah, N. F. (2013). Pembelajaran Edutainment Belanbe Dapat Meningkatkan Kecerdasan Peserta Didik. Cirebon.

Palembang, B. S. (2018). Kertapati Dalam Angka 2018. BPS Kota Palembang.

Sani, R. A. (2014). Pembelajaran Saintifik Untuk Implementasi Kurikulum 2013. Jakarta: Bumi Aksara.

Wena, M. (2012). Strategi Pengembangan Inovatif Kontemporer; Suatu Tinjauan Konseptual Operasional. Jakarta: Bumi Aksara. 